\title{
Piotr Przybylowski
}

Uniwersytet Morski w Gdyni

\section{REKOMENDACJA MONOGRAFII \\ PT. KULTURA JAKOŚCI, DOSKONALOŚCI \\ I BEZPIECZEŃSTWA WORGANIZACJI \\ AUTORSTWA MALGORZATY Z. WIŚNIEWSKIEJ I PIOTRA GRUDOWSKIEGO}

DOI: 10.15611/nit.2019.4.05

Rekomenduję z głębokim przekonaniem monografię pt. Kultura jakości, doskonałości i bezpieczeństwa w organizacji pod redakcją Małgorzaty Z. Wiśniewskiej i Piotra Grudowskiego, wydaprzez Wydawnictwo CeDeWu Sp. z o.o. z siedzibą w Warszawie, jako dzieło interesujące i wartościowe merytorycznie.

Wstęp stanowi dobre, komunikatywne wprowadzenie do treści monografii. W sposób syntetyczny przedstawiono w nim, jaką treść zawierają poszczególne rozdziały. Zwrócono uwagę na konieczność nowego spojrzenia na pojęcie jakości, szczególnie w aspekcie kultury jakości, bezpieczeństwa, doskonałości i tworzenia odpowiedniego klimatu dla tych wartości w organizacji. Wstęp pod względem treści i formy zachęca czytelnika do przeczytania tej monografii i wykorzystania

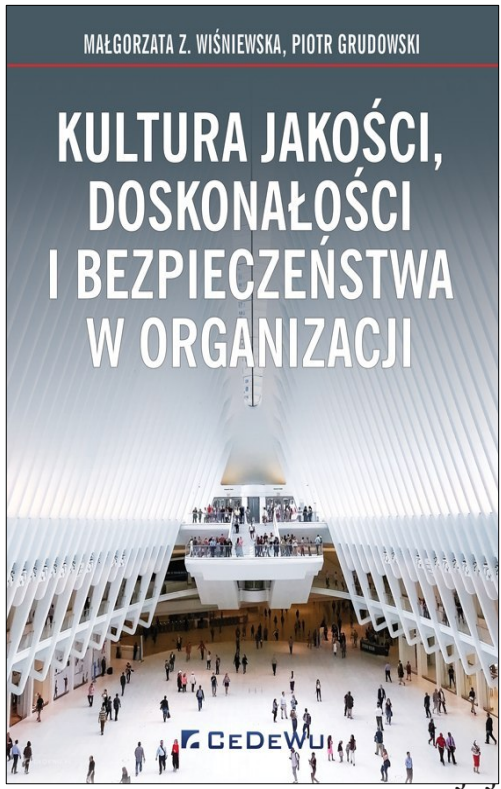
walorów naukowych i praktycznych.

W rozdziale 1 zatytułowanym „Jakość i kultura jakości” w sposób ciekawy i szczegółowy przedstawiono pojęcie jakości i jej znaczenie dla satysfakcji oraz lojalności interesariuszy oraz istotę i rozwój koncepcji kompleksowego zarządzania jakością TQM. Szczególny akcent położono na zagadnienie znaczenia kultury jakości w organizacji oraz znaczenie systemu Six Sigma, Lean Six Sigma i koncepcji Lean. Tę część monografii oparto na wiedzy zaczerpniętej z dobrze dobranej i aktualnej literatury, co daje merytoryczną podstawę do pogłębienia analizowanych zagadnień w kolejnych rozdziałach monografii. 
W rozdziale 2 - pt. „Doskonałość i kultura doskonałości w organizacji” - zawarto ważną treść, która w pełni wpisuje się w merytoryczną warstwę monografii. Omówiono m.in.: pojęcie i znaczenie doskonałości w organizacji, ogólną istotę modeli doskonałości, kulturę doskonałości i ciągłe doskonalenie, inne modele i podejścia służące kształtowaniu doskonałości, a także prestiżowe modele premiujące doskonałość organizacji.

W rozdziale 3 „Cykl doskonalenia PDCA oraz zarządzanie ryzykiem jako podstawa zarządzania systemowego" szczególną uwagę zwrócono na takie zagadnienia, jak: istota systemu zarządzania oraz cyklu PDCA, podejście normatywne do zarządzania jakością, inne normatywne systemy zarządzania i ich integracja, systemowe zarządzanie ryzykiem według normy ISO 31000:2018, zarządzanie ryzykiem i jego istota, jak również wdrażanie i certyfikacja normatywnych systemów zarządzania a krzewienie kultury jakości opartej na orientacji procesowej. Ta część monografii jest dobrze napisana pod względem merytorycznym $\mathrm{z}$ wyważonym odniesieniem do literatury. Autorzy szczególny akcent położyli na istotę zarządzania ryzykiem oraz dość szczegółowo przedstawili werbalnie i graficznie systemowe zarządzanie ryzykiem według normy ISO 31000:2018. W oryginalny sposób przestawili filary procesu zarządzania ryzykiem oraz model systemu zarządzania ryzykiem skonstruowany na podstawie normy ISO 31000. W modelu tym widać relacje pomiędzy wszystkimi elementami systemu zarządzania ryzykiem, a także rolę przywództwa oraz zaangażowanie. Uważam, że stanowi to istotną wartość dodaną tego opracowania.

Należy również zauważyć, że autorzy tej monografii podkreślają rolę koncepcji zarządzania procesowego, która to stanowi podstawę zarządzania projakościowego, a ponadto stwarza optymalne warunki do krzewienia kultury jakości i doskonałości w różnego typu organizacjach. $Z$ zadowoleniem należy więc przyjąć treść głównej tezy, jaką przyjęli Autorzy monografii: „Kultura jakości i doskonałości organizacji tworzy się i rozwija dzięki odpowiednio realizowanej strategii zarządzania procesami w organizacji, przy wsparciu odpowiednio dobranych i stosowanych modeli, zasad i metod zarządzania projakościowego".

Rozdział 4 dotyczy ważnego zagadnienia, jakim jest tytułowe „Bezpieczeństwo jako kluczowy aspekt jakości i doskonałości”. Treść podzielona jest na cztery podrozdziały dotyczące: pojęcia bezpieczeństwa, wybranych aspektów bezpieczeństwa produktów, usług, podmiotów i procesów, kultury bezpieczeństwa jako elementu kultury jakości i doskonałości oraz just culture. Uważam, że rozdział ten stanowi cenną teoretyczną podbudowę dla rozdziału 5. Szczególne znaczenie mają tu dwa podrozdziały, w których ciekawie przedstawiono problematykę kultury bezpieczeństwa i jej wpływ na kulturę jakości i doskonałości oraz just culture. Bazując na właściwie dobranej literaturze, przedstawiono interesujące własne komentarze i przemyślenia dotyczące wybranych definicji i opinii na temat kultury bezpieczeństwa. Autorzy podkreślają, jak ważne jest stworzenie swoistego klimatu dla bezpieczeństwa, czyli atmosfery właściwych i pożądanych odczuć związanych z tym aspektem i jego postrzeganiem w organizacji. 
W budowie i doskonaleniu kultury bezpieczeństwa, niezależnie od jego zakresu podmiotowego i przedmiotowego, istotne znaczenie ma zjawisko just culture, zwane kulturą sprawiedliwego traktowania, kulturą sprawiedliwości lub kulturą raportowania. Autorzy przytaczają tu wyniki badań D. Marxa, amerykańskiego specjalisty w zakresie zarządzania ryzykiem, który zwraca uwagę na daleko idące konsekwencje błędu ludzkiego wewnątrz organizacji medycznych zajmujących się skomplikowanymi procedurami realizowanymi przez zespoły ludzkie. Według autorów monografii just culture to równowaga pomiędzy kulturą obwiniania i nieobwiniania. Oznacza to, że just culture, jeśli funkcjonuje w organizacji, jest dowodem swoistej doskonałości i dojrzałości postaw w zakresie bezpieczeństwa. Podrozdział ten jest wartościowym i ciekawym kompendium wiedzy na temat kultury bezpieczeństwa i jej znaczenia w zarządzaniu procesowym i jakości życia.

Rozdział 5 ma szczególną wartość, zawiera bowiem aspekty naukowe i praktyczne. Przedstawiono w nim tytułowe przykłady narzędzi i metod służących rozpoznaniu oraz ksztaltowaniu kultury jakości i doskonałości. W pierwszej części zaprezentowano rolę narzędzi i metod w zarządzaniu jakością oraz zjawisko samooceny. Autorzy w bardzo czytelny sposób przedstawili i opisali dwanaście ogólnych etapów postępowania w tym zakresie. Dopełnieniem tabelarycznego zestawienia etapów samooceny jest wpisanie w cykl ciągłego doskonalenia PDCA poszczególnych etapów samooceny i zilustrowanie tego w autorskim ujęciu na rysunku. Następnie przedstawiono przykłady kwestionariuszy jako narzędzia do przeprowadzenia samooceny kultury jakości, doskonałości, samooceny kultury bezpieczeństwa i just culture.

W kolejnych podrozdziałach przedstawiono przykłady kwestionariuszy jako narzędzia do przeprowadzenia samooceny kultury bezpieczeństwa pacjenta, samooceny kultury bezpieczeństwa żywności oraz metody wykorzystywane do oceny skuteczności działań doskonalących - w tym wypadku Autorzy podali propozycję wskaźników skuteczności w odniesieniu do zarządzania kadrami i zakupami. W zakończeniu rozdziału przestawiono metody wykorzystywane w zarządzaniu ryzykiem, proponując przykładowe metody możliwe do zastosowania w procesie oceny ryzyka, wskazane w normie ISO/IEC 31010.

Podsumowanie - Jakość 4.0 stanowi bardzo oryginalną i ciekawą treść nawiązującą do najistotniejszych myśli zawartych w monografii. Zadanie współczesnym liderom jakości ośmiu pytań skłania i zachęca ich do twórczego myślenia i działania, by idea Jakości 4.0 dała odpowiednie owoce dla szeroko rozumianej jakości życia.

Cennym dopełnieniem monografii są trzy załączniki, które stanowią:

- Wykaz dokumentów opublikowanych przez ISO, w których zawarte są wymagania dla systemów zarządzania i na podstawie których możliwa jest ich certyfikacja.

- Wykaz dokumentów w trakcie opracowania przez ISO (nowo projektowanych lub w trakcie zmian), w których zawarte są wymagania dla systemów zarządzania.

- Wykaz dokumentów opublikowanych bądź przygotowywanych przez ISO, w których zawarte są wskazówki i wytyczne dla systemów zarządzania - niepodlegające certyfikacji. 
Uważam, że jest to bogate, pomocne zestawienie norm wspierających skuteczne zarządzanie w ujęciu systemowym, na czele z normami należącymi do tzw. rodziny norm ISO serii 9000. Zbiór ten pozwala uświadomić Czytelnikowi, jak ważnym i wymagającym wyzwaniem jest zarządzanie, szczególnie wtedy, gdy winno ono być podporządkowane dodatkowym potrzebom artykułowanym przez kluczowych interesariuszy.

W podsumowaniu stwierdzam, że rekomendowana monografia ma charakter naukowy i jest napisana zgodnie ze współczesną wiedzą w zakresie poruszanej problematyki. Czytelnie ułożono w niej treści, ciekawie ujęto poszczególne zagadnienia, a ponadto właściwie rozłożono akcenty na wiedzę ważną i aktualną z perspektywy teoretycznej i praktycznej. Zamieszczone w monografii rysunki i tabele są czytelne i dobrze skonstruowane. Monografia jest oparta na bogatej ilościowo, aktualnej i dobrze dobranej literaturze, którą stanowią: 211 pozycji o charakterze artykułów naukowych i druków zwartych polsko- i angielskojęzycznych, 20 aktów prawnych i normatywnych oraz netografia.

Książka ta jest wartościowym podręcznikiem akademickim, z którego mogą korzystać studenci uniwersytetów ekonomicznych i przyrodniczych, politechnik, studiujący zarządzanie i marketing, inżynierię i zarządzanie produkcją, zarządzanie jakością, towaroznawstwo, technologię żywności i żywienia. Jej obecność na rynku wydawniczym jest cenną pozycją literaturową w obszarze nauk o zrządzaniu i jakości.

$\mathrm{Z}$ omawianej publikacji mogą korzystać także praktycy zajmujący się organizacją produkcji, marketingiem, dystrybucją wyrobów oraz zarządzaniem środowiskowym. Monografię tę można polecić ponadto menedżerom, doradcom oraz pełnomocnikom do spraw systemów zarządzania. 